Aleksandra Mirek-Rogowska

(1) https://orcid.org/0000-0001-9094-9540

\title{
Wyzwania i przyszłość agencji prasowych w Polsce
}

(6) https://doi.org/10.15633/9788363241131.05

Agencje prasowe, współcześnie nazywane agencjami informacyjnymi ${ }^{1}$, zajmują szczególne miejsce na rynku medialnym. Od początku swego istnienia stanowiły znaczący element w obiegu i rozpowszechnianiu informacji. W ostatnich latach poprzez dynamiczny rozwój technologiczny, powstanie tendencji do poszukiwania informacji w internecie oraz wpływ nowych mediów na prasę, radio i telewizję należy zadać sobie pytanie o współczesną wizję agencji informacyjnych oraz to, jaka czeka je przyszłość.

Rozwój technologii informacyjnych i komunikacyjnych oraz zjawiska zachodzące w internecie w sposób istotny wypływają na to, co dzieje się w naszej rzeczywistości, w tym również na tradycyjne media. Proces przenikania się internetu, telewizji, radia i prasy jest zjawiskiem powszechnym. Dotyczy on również agencji informacyjnych i stanowi jednocześnie jeden z głównych kierunków ich ewolucji po 1989 roku.

Współczesny polski rynek agencji informacyjnych został ukształtowany w wyniku kilku procesów, do których zaliczyć należy przede wszystkim:

- transformację agencji prasowych funkcjonujących w PRL, do których należą Polska Agencja Prasowa (PAP), Polska Agencja „Interpress" (PAI) oraz Centralna Agencja Fotograficzna (CAF),

1 R. Piasecka-Strzelec, Polskie agencje, dz. cyt., s. 185. 
- utrata monopolu informacyjnego przez PAP oraz powstanie i dynamiczny rozwój nowych podmiotów na rynku informacji agencyjnej,

- stale rosnące zapotrzebowanie na różnego rodzaju informacje,

- integrację agencji informacyjnych $\mathrm{z}$ internetem, dostosowanie się do poziomu Web 2.0, co wiązało się z ustaleniem wzajemnych relacji z mediami społecznościowymi, czyli tak zwane wejście agencji informacyjnych w stadium kultury cyfrowej ${ }^{2}$.

W ten sposób na rynku agencji prasowych w Polsce można wyróżnić niewielką, widocznie zróżnicowaną grupę agencji ogólnoinformacyjnych, na przykład PAP, Informacyjna Agencja Radiowa (IAR) i Telewizyjna Agencja Informacyjna (TAI) czy Agencja TVn (TVn News \& Service Agency), oraz liczną grupę agencji prasowych wyspecjalizowanych w różnych kategoriach informacji, jak na przykład Katolicka Agencja Informacyjna (KAI), będąca agencją wyznaniową; Grupa Marketingowa TAI, odpowiadająca za informacje ekonomiczno-finansowe; Agencja Prasowa i Fotograficzna MWMedia, będąca agencją informacyjno-fotograficzną; Media NetPR, która zajmuje się komunikatami informacyjno-reklamowymi; Press-Service Monitoring Mediów, odpowiedzialny za monitoring mediów; a także Agencja Gazeta, która jest agencją fotograficzną, i wiele innych. Odrębną kategorię agencji, będących konkurencją dla krajowych, szczególnie ogólnoinformacyjnych agencji informacyjnych, stanowią biura światowych instytucji, takich jak Thomson Reuters, Associated Press, Bloomberg, mających swoje oddziały również w Polsce.

Rozwój technologiczny i społeczny postawił przed agencjami informacyjnymi nowe wyzwanie, z którym musiały sobie poradzić, by nadal stanowić niezwykle ważny element obiegu i rozpowszechniania informacji.

\section{Pierwsze wyzwanie - cyberprzestrzeń}

Migracja agencji prasowych do cyberprzestrzeni to naturalny proces, będący jednocześnie ostatnim etapem rewolucji informacyjnej, opisywanej przez Paula Levisona, której typowymi cechami są internetyzacja instytu-

2 Zob. R. Piasecka-Strzelec, Kierunki rozwoju, dz. cyt., s. 59-70; R. Piasecka-Strzelec, $M e$ tody i techniki upowszechniania informacji przez wspótczesne polskie agencje informacyjne, „Studia Medioznawcze” 2014, t. 3 nr 58, s. 55-64. 
cji medialnej oraz mediatyzacja internetu, co objawia się za pomocą udostępniania bieżącej zawartości lub materiałów archiwalnych w internecie, tworzeniem ofert na żądanie, a także wzbogacaniem tradycyjnych witryn i portali internetowych o treści i formy dziennikarskie czy audiowizualne wzorowane na linearnych programach radiowych lub telewizyjnych itp. ${ }^{3}$ W ten sposób integracja agencji informacyjnych $\mathrm{z}$ internetem stała się wejściem w stadium kultury cyfrowej i doprowadziła do zaniku tradycyjnych agencji prasowych oraz wykształcenia e-agencji.

To wejście w cyberprzestrzeń przez agencje informacyjne dobrze obrazuje ewolucja, jaka zaszła w PAP, będącej głównym źródłem informacji polskich mediów. W 1994 roku migracja Polskiej Agencji Prasowej do internetu zbiegła się z wkraczaniem profesjonalnych polskich mediów do cyberprzestrzeni oraz komputeryzacją agencji wdrażaną w latach 1991$1994^{4}$. W ten sposób w 1997 roku rozpoczęła ona wydawanie pierwszej w Polsce internetowej gazety codziennej nieposiadającej papierowego wydania po tytułem „Dziennik Internetowego PAP”. Od momentu wejścia agencji prasowej do cyberprzestrzeni zaczęła mieć ona znaczenie nie tylko dla tradycyjnego odbiorcy, lecz także coraz szybciej rozwijających się mediów elektronicznych. W ten sposób PAP zaczęła obsługiwać, oprócz radia, telewizji i prasy, operatorów telefonii komórkowej, portale internetowe, między innymi Onet Biznes, Interia czy RMF.24, czy urzędy i instytucje państwowe ${ }^{5}$. Biuletyn papierowy zastąpiony został przez między innymi kodowany dostęp do strony $\mathrm{w} w \mathrm{w}$, mail, sMs, dostęp za pośrednictwem satelity oraz przy użyciu formatów: .jpg, wideo, .txt, News ML czy www. Ponadto PAP ma do dyspozycji kanał Rss, będący alternatywnym dostępem do zasobów internetu niż standardowe strony www, dzięki któremu podaje kilkadziesiąt wiadomości dziennie. Wzorem światowych agencji informacyjnych w swojej ofercie posiada serwisy multimedialne w postaci tak zwanych pakietów informacyjnych gotowych do wstawienia na stronę, bez wymogu pracy redakcyjnej ze strony odbiorców. Co więcej, oferuje również infogalerie, materiały wideo, aplikacje przeznaczone dla portali internetowych, platform telewizyjnych oraz ogólnodostępne aplikacje na smartfony czy pakiety wiadomości agencyjnych i zdjęć, skierowane do

3 K. Jakubowicz, Polityka medialna a media elektroniczne, Warszawa 2008, s. 78-79.

4 L. Olszański, Dziennikarstwo internetowe, Warszawa 2006, s. 12-13.

5 Tamże, s. 25-29. 
mediów lub operatorów komórkowych, rozbudowane serwisy komercyjne i tematyczne (tekstowe, fotograficzne, audiowizualne) tworzone specjalnie na zamówienie, reklamę online oraz emitent ${ }^{6}$. PAP oferuje również techniczną i merytoryczną organizację wydarzeń, obsługę medialną i promocję konferencji prasowych, spotkań biznesowych czy debat branżowych, a także transmisje online ${ }^{7}$. Jest ona również wydawcą kilku portali internetowych promujących profesjonalną wiedzę oraz będących płaszczyzną wymiany informacji i opinii (na przykład Nauka w Polsce, GPW Infosfera, dzieje.pl, samorząd.pap.pl czy biznes.pap.pl). Podsumowaniem wejścia do cyberprzestrzeni przez PAP może być jej obecność na portalach takich jak Facebook, Twitter, YouTube czy LinkedIn.

O ile Polska Agencja Prasowa musiała przejść proces zarówno komputeryzacji, jak i reorganizacji, o tyle inne agencje powstałe po $1989 \mathrm{roku}$, jak na przykład Informacyjna Agencja Radiowa (IAR), Katolicka Agencja Informacyjna (KAI) oraz TVN News, należące również do ścisłej czołówki agencji informacyjnych w Polsce, od początku swojego istnienia funkcjonują jako e-agencje.

Informacyjna Agencja Radiowa uznawana jest za największą elektroniczną agencję informacyjną na polskim rynku ${ }^{8}$. Jej głównym produktem jest serwis internetowy zawierający materiały tekstowe i dźwiękowe. Dystrybucja jej serwisów odbywa się podobnie jak PAP - za pośrednictwem satelity oraz internetu. Obecna jest również na portalach społecznościowych, takich jak Facebook i Twitter. W roku 2010 IAR uruchomiła własne radio internetowe - Polskie Radio 24, w którego ofercie znaleźć można, oprócz serwisów informacyjnych IAR, rozmowy na żywo z ekspertami i znanymi osobami z życia publicznego, materiały przygotowane przez pracowników IAR oraz korespondentów zagranicznych Polskiego Radia. Inną wspomnianą już agencją internetową jest Katolicka Agencja Informacyjna, będąca pierwszą w Europie Środkowo-Wschodniej agencją wyzna-

6 Jest to dystrybucja oficjalnych informacji ze spółek giełdowych, spółek publicznych, otwartych funduszy emerytalnych powszechnych towarzystw, która gwarantuje bezpośredni i szybki dostęp do dziennikarzy i inwestorów za pomocą kodowanych serwisów informacyjnych oraz ogólnodostępnych stron internetowych PAP. Zob. R. Piasecka-Strzelec, Metody i techniki upowszechniania informacji, dz. cyt., s. 59.

7 PAP: Nasze ustugi, https://pap-mediaroom.pl/nasze-uslugi, 28.09.2020.

8 IAR: Informacyjna Agencja Radiowa (IAR), https://www.polskieradio24. $\mathrm{pl} / 78$, Informacyjna-Agencja-Radiowa, 28.09.2020. 
niową. Jej serwis informacyjny dostępny jest za pośrednictwem internetu, a także poszczególnych mediów społecznościowych. W swoim serwisie zamieszcza codziennie kilkadziesiąt depesz, analiz, wywiadów z całego świata, ze szczególnym uwzględnieniem Polski i Watykanu. Dostęp zależny jest od posiadanego profilu. Przykładowo po wykupieniu abonamentu Profil Business Plus posiada się nielimitowany miesięcznie dostęp do serwisu oraz dostęp do archiwum $28 \mathrm{dni}$ wstecz, a posiadając przekaz satelitarny, ma się możliwość otrzymywania serwisu za pośrednictwem łączy satelitarnych PAP ${ }^{9}$. W swojej ofercie ma również możliwość przygotowania i obsługę medialną konferencji prasowych, briefingów, spotkań dla mediów i wielu innych wydarzeń ${ }^{10}$. Do elektronicznych serwisów zaliczyć można również serwis dźwiękowy audiokAi i serwis fotograficzny fotoKAI.

Wyróżniającą się na tle innych agencji ogólnoinformacyjnych i specjalizującą się w produkcji krótkich form wideo, takich jak materiały newsowe, reportaże i „wirale”, jest Tvn News \& Service Agencies. Powstała w 2009 roku jako agencja telewizyjna. Dostarcza newsowe i archiwalne materiały wideo do serwisów internetowych, na platformy nowych mediów oraz świadczy telewizyjne usługi produkcyjne i broadcastingowe. Dzięki umowie z Agencją Gazeta, specjalizującą się w fotografii, Agencja TVN posiada dobrze zaopatrzony oraz unikatowy pakiet złożony $\mathrm{z}$ materiałów fotograficznych i wideo. Co więcej, wykazuje ona dużą aktywność na rynku zagranicznym, współpracując z globalnymi agencjami informacyjnymi, stacjami telewizyjnymi oraz ze stowarzyszeniem prywatnych nadawców ENEx, dostarczając materiały wideo z Polski do dalszej dystrybucji na świecie. Dynamiczny rozwój i ogromne osiągnięcia Agencja TVN zawdzięcza wizualizacji treści, która jest typowa dla kultury cyfrowej, w końcu „tekst i zdjęcia to za mało. Podstawowym źródłem informacji dla odbiorców stało się wideo. Dzisiaj news nie istnieje bez wideo. Żywy obraz pokazuje emocje, przekazuje więcej prawdy o wydarzeniach [...]. Kto ma wideo, ten ma przewagę nad konkurencją"11.

Ta współczesna, cyfrowa postać agencji informacyjnych, zdolna do przekazywania wszystkich elementów usług multimedialnych (tekst,

9 KAI: Dostęp do serwisu, https://kair.ekai.pl/dispatch_access, 28.09.2020.

10 KAI: Centrum Medialne, https://kair.ekai.pl/centrum_medialne, 28.09.2020.

11 R. Piasecka-Strzelec, Przeksztatcenia i zmiany, dz. cyt., s. 97. 
obraz, wideo, dźwięk), wykorzystuje internet do dystrybucji swoich produktów i usług, a także jako sposób na dotarcie do nowych odbiorców. W ten sposób „klasyczne” agencje prasowe, określane wcześniej mianem „fabryk informacji”, przekształciły się w cybernetyczne fabryki informacji (ang. cyberfactories) ${ }^{12}$ zajmujące się produkcją newsów. Cyfryzacja zaliczana do technicznych fundamentów społeczeństwa sieci w znaczący sposób podniosła zdolności komunikacyjne agencji informacyjnych, takie jak: wierność, selektywność, obfitość bodźców.

\section{Drugie wyzwanie - media społecznościowe}

Po zaaklimatyzowaniu się w cyberprzestrzeni przyszła kolej na następne wyzwanie - media społecznościowe, które stały się pełnoprawnym komponentem współczesnego pejzażu medialnego. Według Instytutu Monitorowania Mediów „media społecznościowe stają się pełnoprawnym kanałem informacyjnym. [...] media czerpią newsy i informacje bezpośrednio z platform społecznościowych, co nieco przypomina pozyskiwanie informacji z agencji informacyjnych"13, co ponownie sprowadziło pesymistów do wysnucia tezy o bliskim upadku agencji prasowych. Co więcej, niekiedy pojawiały i nadal pojawiają się głosy, że materiały dostępne w platformach społecznościowych są atrakcyjniejsze niż te oferowane przez agencje ${ }^{14}$. Jednakże często kwestią dyskusyjną staje się wiarygodność mediów społecznościowych, w których istnieje niekiedy zjawisko chaosu informacyjnego, stanowiącego ciemną stronę swobody komunikacji, którą dają media społecznościowe. W dobie fake newsów na korzyść agencji informacyjnych przemawia przede wszystkim fakt, że depesza agencyjna, w przeciwień-

12 Zob. B. Czarniawska, Jak produkuje się wiadomości w cyberfabrykach, „Zarządzanie Mediami" 2019, t. 7, nr 4, s. 193-214.

13 Instytut Monitorowania Mediów, Facebook $i$ Twitter bardziej opiniotwórcze niż telewizja. Kiedy zrównają się z agencjami informacyjnymi?, https://www.imm.com.pl/facebook-i-twitter-bardziej-opiniotworcze-niz-telewizja-kiedy-zrownaja-sie-z-agencjami-informacyjnymi/, 28.09.2020.

14 Zob. R. Piasecka-Strzelec, Pierwsze źródta informacji. Agencje informacyjne versus social media, w: Ksiązka, biblioteka, informacja. Między podziałami a wspólnotą IV, red. J. Dzieniakowska, M. Olczak-Kardas, Kielce 2015. s. 553-561; L. Olszański, Media i dziennikarstwo internetowe, Warszawa 2012. 
stwie do informacji publikowanych na portalach społecznościowych, jest informacją autoryzowaną przez agencję, czyli potwierdzoną i wiarygodną.

Social media są impulsem do rozwoju dla agencji informacyjnych, a także stają się nowym obszarem ich działalności, o czym świadczy obecność agencji prasowych na Facebooku, Twitterze, YouTubie, LinkedInie i innych portalach społecznościowych i wykorzystywanie ich jako kanałów do rozpowszechniania informacji. W ten sposób można uznać, że media społecznościowe pełnią funkcję tak zwanych mediów zaradczych, „dając więcej niż zabierając - wnosząc nie tyle absolutne ulepszenie, co ulepszenie netto [...]. Ich działanie przynosi zarówno pewien postęp, jak i stwarza nowe wyzwania [...]. Jeżeli w tym procesie otrzymamy pewien zysk netto, dokona się postęp jak zwykle niepewny i niedoskonały"15.

Współpraca agencji informacyjnych i mediów społecznościowych spowodowała, że ich użytkownicy mają możliwość nie tylko komentowania wiadomości dostępnych na witrynie internetowej agencji informacyjnej, lecz także ich współtworzenia. Możliwość tego typu interakcji stwarza utworzenie i dołączenie ich do oferty danej instytucji powiadomień o wydarzeniach, tak zwanej infoskrzynki, pisania blogów i artykułów korespondencyjnych z treścią wiadomości. Ciekawym zjawiskiem i jednocześnie nową generacją „agencji 3.0” są tak zwane agencje social media, które $\mathrm{w}$ swojej ofercie mają działania z zakresu marketingu, kampanie reklamowe i PR-owe w mediach społecznościowych. Do tej grupy należą między innymi Agencja Social Media, Agencja Social Media Websoul, Social Media Now.

\section{Trzecie i czwarte wyzwanie - tabloidyzacja i komodyfikacja}

Obecnie coraz częściej zwraca się uwagę na procesy typowe dla nowych technologii komunikacyjnych polegające nie tylko na ewolucji przekazów agencyjnych od kultury mediów drukowanych do kultury mediów audiowizualnych i komputerowych, lecz także od ich uniformizacji do dywersyfikacji.

15 P. Levinson, Miękkie ostrze. Naturalna historia i przyszłość rewolucji informacyjnej, Warszawa 1999, s. 175 . 
Tabloidyzacja mediów jest częścią szerszych zjawisk społeczno-kulturowych, takich jak komercjalizacja, konsumpcjonizm czy globalizacja, które miały wpływ na zmianę roli mediów, poprzez wzrost znaczenia roli rozrywkowej kosztem ich innych ról, jak na przykład informacyjnej, edukacyjnej, wychowawczej itd. Nadawcy medialni na pierwszym miejscu stawiają szybkość i atrakcyjność przekazu, a w dalszej kolejności liczą się dla nich jakość przekazywanych treści, rzetelność dziennikarska czy obiektywizm. Odpowiedzią na nowe wyzwania rynku mediów jest powstanie w ostatnich latach zmodyfikowanej formuły agencji informacyjnej, usiłującej pogodzić zarówno informowanie odbiorców o tym, co ważne - hard news z ich zabawianiem, za pomocą informacji typu soft news.

Produktem procesu tabloidyzacji mediów są niewielkie, prywatne agencje informacyjno-fotograficzne zorientowane na tematykę lifestylową, związaną głównie $\mathrm{z}$ informacjami typu soft news. Pionierami w tej dziedzinie były Agencja Prasowa i Fotograficzna Mw Media (dawniej Microway Media), AKPA Polska Press oraz ValPress ${ }^{16}$. Klasycznym przykładem współczesnej agencji nastawionej na przekazywanie informacji lekkich w formie i treści stanowi Agencja Informacyjna Newseria Lifestyle (powstała w 2011 roku). Inną agencją starającą się połączyć zjawiska infotainment oraz politainment jest Krajowa Agencja Prasowa i Fotograficzna (KAPiF), która w swojej ofercie ma materiały dotyczące gwiazd filmu i estrady, a także znanych i popularnych polityków. Również duże, ogólnoinformacyjne agencje postanowiły wejść w rolę dostawcy rozrywki, uruchamiając specjalny serwis nastawiony na informację lifestylową. Przykładowo Polska Agencja Prasowa utworzyła w 2009 roku PAP Lifestyle. Firmowanie informacji o charakterze rozrywkowym przez poważną agencję, jaką jest PAP, która reprezentuje obraz rzeczywistości społeczno-politycznej w zgodzie z paktem faktograficznym, pozostaje w ścisłym związku z zasadą opłacalności oraz dążeniem do pozyskania jak największej liczby odbiorców. Jest to zatem przykład „świadomej strategii przyjmowanej po to, aby dotrzeć do medialnego konsumenta"17.

Odrębną kwestię stanowi wpływ komodyfikacji ${ }^{18}$ mediów na zawartość serwisów agencji informacyjnych. Coraz wyraźniejsza staje się tendencja

16 Zob. R. Piasecka-Strzelec, Kierunki rozwoju, dz. cyt., s. 69-7o.

17 A. Stuart, Kultura newsów, Kraków 2006, s. 204.

18 Polegającej na determinowaniu wartości przekazów dziennikarskich poprzez ich przy- 
do tworzenia serwisów z myślą o ich sprzedawalności. „Wczesną formę komodyfikacji można [...] dostrzec w działalności pierwszych agencji prasowych. Chcąc sprzedać swoje serwisy możliwie największej liczbie bardzo wówczas upolitycznionych i stronniczych gazet, agencje te w celach handlowych przyjęły zasadę obiektywizmu i bezstronności swoich informacji, by serwisy te były do przyjęcia dla wszystkich redakcji. Inaczej mówiąc zamieniły informację w towar" ${ }^{\prime 19}$. Przyczynia się to do standaryzacji, która bardziej widoczna jest na przykładzie właśnie agencji informacyjnych, szczególnie mniejszych i wyspecjalizowanych w konkretnej dziedzinie niż $\mathrm{w}$ innych organizacjach medialnych ${ }^{20}$. Co więcej, $\mathrm{z}$ definicji produktem agencji prasowych jest „tylko wiadomość”, pozbawiona opinii, komentarza, przymiotników. Standardowe wiadomości są bezpieczne i opłacalne, ponieważ to ich odbiorcy, płacąc jednocześnie za możliwość otrzymania surowego materiału, dokonują stosownej interpretacji, dostosowanej do własnego użytku. Z drugiej strony owa standaryzacja informacji może przyczynić się do coraz to większej rywalizacji pomiędzy poszczególnymi agencjami informacyjnymi, które by przetrwać, będą musiały ze sobą współpracować. W ten sposób będzie się miało do czynienia ze zjawiskiem konkurencji w ramach współpracy.

\section{Jaka przyszłość przed agencjami prasowymi?}

Niedawny kryzys finansowy odbił się zarówno na firmach świadczących usługi finansowe, jak i na dostawcach usług medialnych, takich jak prasa, telewizja, radio czy portale internetowe. W związku z tym należałby sądzić, że agencje prasowe, które im niejako służą, również powinny mieć kłopoty. Tak się jednak nie stało. Jak potwierdzają badania Boczkowskiego $^{21}$, wzrost agencji informacyjnych jest nieunikniony, co jest kon-

datność do zaspokojenia określonych potrzeb odbiorców. Wyrazem tej przydatności jest chęć odbiorców do płacenia za poznanie treści danych przekazów. Zob. W. Furman, Czym jest komodyfikacja i tabloidyzacja przekazów dziennikarskich? O splocie różnych procesów, „Rocznik Bibliologiczno-Prasoznawczy” 2016, t. 8, nr 19, s. 13-24.

19 K. Jakubowicz, Media a demokracja wXXI wieku. Poszukiwanie nowych mediów, Warszawa 2013, s. 124.

20 Zob. B. Czarniawska, dz. cyt., s. 193-214.

21 Za: tamże, s. 208. 
sekwencją zwiększonego zapotrzebowania na gotowe informacje, przy niejednokrotnie braku funduszy podmiotów medialnych na utrzymanie odpowiedniej liczby dziennikarzy do zdobywania potrzebnych informacji. Co więcej, „nic nie wskazuje na to, aby agencje informacyjne zeszły ze sceny medialnej przed pozostałymi mediami, skoro są dla niech przydatne, oszczędzają im czas i pieniądze"22.

Rozwój społeczeństwa informacyjnego, kreowanie się nowych form komunikacji, rozwój technologiczny, w tym pojawienie się cyberprzestrzeni, stały się dużym wyzwaniem, ale również szansą dla istniejących i nowo powstających agencji informacyjnych. Podobnie jak ich odbiorcy - radio, telewizja, prasa - którzy weszli do internetu, tak i agencje prasowe zintegrowały się z nim, wykorzystując jego zalety w zakresie dystrybucji i pozyskiwania informacji. Jak zauważył Rutkiewicz, „media zmieniają tylko swoją formę, a nie znikają. Więc i agencje pewnie pozostaną w naszym świecie. Mało widoczne dla przeciętnego konsumenta mediów, ale bardzo potrzebne dla systemu mediów"23.

Internet oprócz wielu zalet w zakresie poszukiwania i rozpowszechniania informacji jest również „globalnym śmietnikiem”, gdzie każdy może napisać wszystko, co chce, bez względu na poziom, wartość czy wiarygodność. Jak trafnie zauważył Leszek Olszański, „mając tę świadomość, nikt nie wątpi w to, że profesjonalne media w dalszym ciągu są potrzebne" ${ }^{24}$. O dynamicznym rozwoju mediów społecznościowych, w których upatrywano końca agencji prasowych, mówił między innymi Michael Wolff. Twierdził on, że Twitter jako serwis społecznościowy ma możliwość i chęć wykorzystania swojego pełnego potencjału w celu stania się narzędziem powszechnie wykorzystywanym zarówno przez odbiorców wiadomości, jak i dziennikarzy tworzących materiały informacyjne, w ten sposób stając się pośrednikiem, który w dużym stopniu może zastąpić agencje informacyjne $^{25}$. Agencje prasowe potrafiły wyjść zwycięsko z tego starcia, zaznaczając swoją obecność na portalach społecznościowych i wykorzystując

22 I Rutkiewicz, Czterej potentaci i CNN, „Rzeczpospolita” 28.10.20oo, http:demopol.pl/ w88, html, 4.05.2013.

23 Tamże.

24 L. Olszański, Media i dziennikarstwo internetowe, dz. cyt., s. 102-103.

25 T. Baliszewski, Rewolucja $w$ dziennikarstwie? Twitter szuka szefa dziatu medialnego, https://natemat.pl/60743,rewolucja-w-dziennikarstwie-twitter-szuka-szefa-dzialu-medialnego, 29.09.2020. 
ich możliwości do interakcji z odbiorcami poprzez umożliwienia komentowania oraz tworzenia informacji. Co więcej, media społecznościowe stały się nowym kanałem dla rozpowszechniania serwisów agencyjnych.

Tabloidyzacja i komodyfikacja również stały się swego rodzaju szansą dla agencji prasowych na zdobycie nowych odbiorców. Jak trafnie zauważyli eksperci London School of Economics, którzy prowadzili badania na temat informacji we współczesnym świecie, news nigdy nie umrze - kwestią są tylko kanały komunikacji. O ile kanały komunikacji ulegają zmianie, o tyle informacja zawsze pozostanie w cenie ${ }^{26}$.

Wszelkie zmiany, procesy społeczne, polityczne czy technologiczne, pojawiające się nowe komponenty pejzażu medialnego, stanowiły w przeszłości i będą stanowić w przyszłości wyzwania dla agencji prasowych, lecz z drugiej strony otworzyły i będą otwierać przed nimi nowe możliwości przyspieszenia obiegu i wzbogacenia informacji ${ }^{27}$, zdobycia nowych odbiorców swoich treści, będących jednocześnie swego rodzaju ich klientami.

26 M. Rosołowski, Przyszłość agencji informacyjnych leży w ręku państwa, http://instytutstaszica.org/2019/03/25/przyszlosc-agencji-informacyjnych-lezy-w-reku-panstwa/, 29.09.2020.

27 I. Rutkiewicz, Czterejpotentaci i $C N N$, dz. cyt. 
A. Uniwersytet Papieski

Ifor Jana Pawła II

w Krakowie 